\title{
Effect of Planting Methods and Gypsum Application on Yield and Water Productivity of Wheat under Salinity Conditions in North Nile Delta
}

\author{
Hesham Aboelsoud ${ }^{1,2}$, Bernard Engel ${ }^{1, *}$ and Khaled Gad ${ }^{3}$ \\ 1 Department of Agricultural \& Biological Engineering, Purdue University, West Lafayette, IN 47907, USA; \\ haboelso@purdue.edu \\ 2 Soil, Water \& Environment Research Institute (SWERI), Agricultural Research Centre (ARC), \\ Giza 12112, Egypt \\ 3 Wheat Research Department Field Crop, Research Institute, Agricultural Research Centre (ARC), Giza 12112, \\ Egypt; khaledgad1972@yahoo.com \\ * Correspondence: engelb@purdue.edu
}

Received: 1 June 2020; Accepted: 9 June 2020; Published: 16 June 2020

\begin{abstract}
Salinity and water shortage are the most important factors limiting crop productivity, so increasing the productivity of salt-affected soils is important to address the global food gap. Two field experiments were conducted under typical farm conditions in the North Nile Delta to study the effect of planting methods and gypsum application on wheat yield and water productivity under a range of water and soil salinity levels. In the first experiment, wheat was treated with gypsum ( $25 \%, 75 \%$, and $100 \%$ gypsum-requirement) with moderate or high salinity in soil and water. The second experiment was conducted for two seasons at two sites to test three planting methods (flat, 60-cm furrows, and 120-cm raised-beds) under normal or high salinity levels of both soil and water. The results showed that gypsum alleviated the hazardous effects of salinity stress on grain yield. Raised furrows or beds under higher salinity levels increased soil salinity, and soil salinity was slightly increased with flat plots. Higher yields, water savings, and water productivities were achieved with raised furrows or beds under normal salinity. To improve yield under normal salinity conditions, raised beds are the recommended planting method. Furthermore, gypsum application in cultivated fields can mitigate the negative effects of salinity stress.
\end{abstract}

Keywords: wheat; salinity; gypsum; planting method; raised beds; water productivity

\section{Introduction}

Osmotic stress due to drought and salinity adversely affects plant productivity, of which drought is considered as the most devastating [1]. The major reasons for land degradation in irrigated lands in arid and semi-arid conditions are water logging and salinization [2]. However, the Nile Delta is threatened by water logging, soil compaction, salinization, and alkalization [3]. With the use of remote sensing and geographic information system (GIS) analyses, land degradation has mainly been found to be associated with over-irrigation [4]. About 29\% of studied areas in Egypt have been found to be marginally suitable or unsuitable for wheat due to the adverse effects of soil's physical and chemical properties [5], and a negative correlation between soil salinity and biomass yield has been found [6]. Jungklang et al. [7] showed that plant height and fresh weight were decreased as a result of water-deficit stress.

The World Bank [8] reported that salinization caused by improper irrigation practices affects about $24 \%$ of all irrigated land, and the productivity of about $10 \%$ of these areas has declined severely. Therefore, improving the production per area and water unit are the major options available to meet 
increases in food demand [9]. This can be achieved by using proper irrigation management, such as with planting methods. Hobbs et al. [10] reported that raised bed planting helps to improving water distribution and efficiency without sacrificing yield. On the other hand, they reported a yield loss of $10 \%$ with a $45-55 \mathrm{~cm}$ furrow width for sensitive wheat cultivars, and there was no loss for the least sensitive cultivars; meanwhile, the yield loss of all cultivars with furrow widths above $60 \mathrm{~cm}$ was confirmed [11], possibly due to a lower population per unit area. Zhang et al. [12] concluded that lower water consumption, higher water use efficiency, and higher wheat yields were achieved with raised bed planting compared to planting with the traditional flat planting method. Freeman et al. [13] found that grain yields of four winter wheat varieties were not statistically different between the bed and conventional planting systems, but the bed planting system had to be used to conserve moisture. In Mexico, Sayre and Hobbs [14] found that bed planting $(70-80 \mathrm{~cm})$ with two or three rows of wheat on top reduced water requirements by $25 \%$ compared to flat planting. Hassan et al. [15] revealed that wheat raised beds demonstrated $13 \%, 36 \%$, and $50 \%$ higher grain yields, water savings, and water productivities, respectively, than that with flat planting. Li Quanqia et al. [16] reported that the wheat yield increased with furrows over that with uniform row planting, wide-narrow row planting, and bed planting by $0.466,0.430$, and $0.804 \mathrm{t} \mathrm{ha}^{-1}$, respectively, due to the vertical distribution of photo-synthetic active radiation. Thompson [17] concluded that raised beds increased winter cereal crop yields compared to the border design because of a decrease of waterlogging. Beecher et al. [18] reported that high yields of irrigated winter cereals crops grown in heavy clay soils can be achieved with the raised beds design. Finally, there are many advantages with growing wheat on beds, but in saline-sodic situations, the performance of wheat on beds can be inferior to conventional flat systems [19].

Saline clay soils with a low permeability are found in the North Nile Delta. Therefore, the reclamation process of salt-affected soils to alleviate adverse effects of salinity may be achieved by the application of soil amendments such as gypsum $\left(\mathrm{CaSO}_{4} \cdot 2 \mathrm{H}_{2} \mathrm{O}\right)$ and compost. These practices are increasingly important tools for improving crop productivity in many regions [20,21]. Recently, gypsum has been used as a method for alleviating water quality problems, and it has been found to lead to better soil infiltration and improvements of crop rooting, consequently boosting crop yield [22]. The permeability of clay soils is strongly dependent on the type of exchangeable cations, and it decreases with increasing the exchangeable sodium percentage (ESP) [23]. The application of gypsum increases soluble $\mathrm{Ca}^{2+}$, thus helping to overcome the dispersion effects of $\mathrm{Na}^{+}$and to promote structure development in dispersed soils. Elsaka et al. [24] found that soluble Ca and chitosan positively affected plant height, 100-grain weight, cobs and straw yields of maize, and it slightly decreased soil electric conductivity $\left(E C_{e}\right)$, the sodium adsorption ratio $\left(\mathrm{SAR}_{\mathrm{e}}\right)$, and ESP values, these materials were able to alleviate the adverse effects of salinity on maize productivity under salt stress. On the other hand, Makoi and Verplancke [25] reported that using gypsum in the amelioration of saline soils is one way of improving agricultural productivity by overcoming salt stress. In addition, Ghafoor et al. [26] reported that brackish water becomes hazardous because of high EC $\left(>1.0 \mathrm{dS} \mathrm{m}^{-1}\right)$ and SAR $(>10.0)$ values. To lower high EC in water, dilution with low-electrolyte water is the only option, while use of any amendment such as gypsum increases its quality. Bayoumy et al. [27] reported that gypsum, compost, and biochar increased wheat grain yield and decreased soil $\mathrm{EC}_{\mathrm{e}}$. Therefore, the current study aimed to assess the effect of raised beds and gypsum application on the yield and water productivity of wheat cultivated in salt-affected soils under typical farm conditions.

\section{Materials and Methods}

Two field experiments were conducted in private farms of the Hafir area (which lies between the longitude of $31^{\circ} 21^{\prime} 50.46^{\prime \prime}-31^{\circ} 21^{\prime} 51.99^{\prime \prime}$ and the latitude of $31^{\circ} 13^{\prime} 18.14^{\prime \prime}-31^{\circ} 3^{\prime} 18.18^{\prime \prime}$ ) and the Talkha District (which lies between the longitude of $31^{\circ} 17^{\prime} 34.79^{\prime \prime}-31^{\circ} 17^{\prime} 36.23^{\prime \prime}$ and the latitude of $31^{\circ} 3^{\prime} 22.07^{\prime \prime}-31^{\circ} 13^{\prime} 16.19^{\prime \prime}$. The two sites are located in the same governorate (Al-Dakahlia Gov., 
North Delta, Egypt), and the distance between the sites is $20 \mathrm{~km}$ with no observed difference in the weather conditions during the 2015-16 and 2016-17 seasons.

Soil samples were taken from each experimental site before and after the experiment. The soil and irrigation water properties are shown in Tables 1-4.

Table 1. Chemical analysis of soil in the experimental sites before cultivation. EC: electrical conductivity;

SAR: sodium adsorption ratio.

\begin{tabular}{|c|c|c|c|c|c|c|c|c|c|c|c|}
\hline \multirow{2}{*}{$\begin{array}{c}\text { Salinity } \\
\text { Level }\end{array}$} & \multirow{2}{*}{$\begin{array}{c}\text { Depth } \\
\text { (cm) }\end{array}$} & \multirow{2}{*}{$\begin{array}{c}\text { ECe } \\
\mathrm{dS} \mathrm{m}^{-1}\end{array}$} & \multicolumn{4}{|c|}{ Cations (meq/L) } & \multicolumn{4}{|c|}{ Anions (meq/L) } & \multirow{2}{*}{ SAR } \\
\hline & & & $\mathrm{Na}^{+}$ & $\mathrm{K}^{+}$ & $\mathrm{Ca}^{2+}$ & $\mathrm{Mg}^{2+}$ & $\mathrm{CO}_{3}{ }^{-2}$ & $\mathrm{HCO}_{3}^{-}$ & $\mathrm{Cl}^{-}$ & $\mathrm{SO}_{4}{ }^{-2}$ & \\
\hline \multirow{3}{*}{$\begin{array}{c}\mathrm{S}_{0} \\
\text { Talkha }\end{array}$} & $0-30$ & 2.50 & 16.6 & 0.6 & 7.8 & 2.9 & 0.0 & 2.1 & 10.5 & 15.3 & 7.2 \\
\hline & $30-60$ & 2.65 & 16.9 & 0.6 & 7.9 & 2.9 & 0.0 & 3.5 & 10.2 & 14.6 & 7.3 \\
\hline & $60-90$ & 2.78 & 17.5 & 0.7 & 7.5 & 3.2 & 0.0 & 4.0 & 11.9 & 13.0 & 7.6 \\
\hline \multirow{3}{*}{$\begin{array}{c}S_{1} \\
\text { Hafire }^{1}\end{array}$} & $0-30$ & 9.00 & 71.5 & 1.6 & 24.2 & 10.5 & 0.0 & 3.5 & 6.5 & 97.8 & 17.2 \\
\hline & $30-60$ & 9.94 & 78.2 & 2.1 & 27.1 & 12.1 & 0.0 & 4.7 & 8.2 & 106.6 & 17.7 \\
\hline & $60-90$ & 10.55 & 83.4 & 2.5 & 29.3 & 13.6 & 0.0 & 4.9 & 8.9 & 115.0 & 18.0 \\
\hline \multirow{3}{*}{$\begin{array}{c}\mathrm{S}_{2} \\
\text { Hafire }^{2}\end{array}$} & $0-30$ & 12.30 & 88.1 & 0.9 & 39.8 & 19.3 & 0.0 & 3.6 & 6.5 & 138.0 & 16.2 \\
\hline & $30-60$ & 12.92 & 92.1 & 1.1 & 41.2 & 22.9 & 0.0 & 4.3 & 8.2 & 144.8 & 16.3 \\
\hline & $60-90$ & 13.55 & 98.5 & 1.5 & 43.8 & 24.6 & 0.0 & 5.5 & 8.9 & 154.0 & 16.8 \\
\hline
\end{tabular}

Table 2. Soil physical properties of the root zone in the experimental fields.

\begin{tabular}{|c|c|c|c|c|c|c|c|c|c|}
\hline \multirow{2}{*}{ Location } & \multicolumn{3}{|c|}{ Particle Size Distribution (\%) } & \multirow{2}{*}{$\begin{array}{c}\text { Soil } \\
\text { Texture }\end{array}$} & \multirow{2}{*}{$\begin{array}{l}\text { Bulk Density } \\
\qquad\left(\mathrm{g} \mathrm{cm}^{-3}\right)\end{array}$} & \multirow{2}{*}{$\begin{array}{c}\text { Porosity } \\
\text { (\%) }\end{array}$} & \multicolumn{3}{|c|}{ Soil Moisture Characteristics (\%) } \\
\hline & Clay & Silt & Sand & & & & $\begin{array}{c}\text { Field } \\
\text { Capacity }\end{array}$ & $\begin{array}{l}\text { Wilting } \\
\text { Point }\end{array}$ & $\begin{array}{c}\text { Available } \\
\text { Water }\end{array}$ \\
\hline Talkha & 52.6 & 29.1 & 18.3 & clayey & 1.22 & 54.0 & 41.1 & 21.4 & 19.7 \\
\hline Hafir ${ }^{1}$ & 50.9 & 25.4 & 23.7 & clayey & 1.25 & 52.8 & 42.3 & 21.6 & 20.7 \\
\hline Hafir $^{2}$ & 52.2 & 25.5 & 22.3 & clayey & 1.24 & 53.2 & 41.9 & 21.1 & 20.8 \\
\hline
\end{tabular}

Table 3. Chemical analysis of irrigation water for the three sites.

\begin{tabular}{|c|c|c|c|c|c|c|c|c|c|c|}
\hline \multirow{2}{*}{$\begin{array}{l}\text { Salinity } \\
\text { Level }\end{array}$} & \multirow{2}{*}{$\begin{array}{c}E C_{w} \\
\left(\mathrm{dS} \mathrm{m}^{-1}\right)\end{array}$} & \multicolumn{4}{|c|}{ Cations (meq/L) } & \multicolumn{4}{|c|}{ Anions (meq/L) } & \multirow{2}{*}{ SAR } \\
\hline & & $\mathrm{Na}^{+}$ & $\mathrm{K}^{+}$ & $\mathrm{Ca}^{2+}$ & $\mathrm{Mg}^{2+}$ & $\mathrm{CO}_{3}{ }^{-2}$ & $\mathrm{HCO}_{3}^{-}$ & $\mathrm{Cl}^{-}$ & $\mathrm{SO}_{4}^{-2}$ & \\
\hline $\mathrm{S}_{0}$ (Talkha) & 0.50 & 2.7 & 0.3 & 1.0 & 0.7 & 0.0 & 3.4 & 0.7 & 0.5 & 2.9 \\
\hline $\mathrm{S}_{1}$ (Hafire $\left.^{1}\right)$ & 4.00 & 22.5 & 0.7 & 11.6 & 7.7 & 0.0 & 3.5 & 0.7 & 38.3 & 7.2 \\
\hline $\mathrm{S}_{2}\left(\right.$ Hafire $\left.^{2}\right)$ & 7.80 & 45.9 & 1.0 & 26.5 & 13.5 & 0.0 & 3.5 & 0.8 & 82.6 & 10.3 \\
\hline
\end{tabular}

Table 4. Chemical properties of soil and irrigation water in the gypsum experimental sites. ESP: exchangeable sodium percentage.

\begin{tabular}{|c|c|c|c|c|c|c|c|c|c|c|c|c|}
\hline \multirow{2}{*}{$\begin{array}{c}\text { Salinity } \\
\text { Level }\end{array}$} & \multirow{2}{*}{$\begin{array}{l}\text { Depth } \\
\text { (cm) }\end{array}$} & \multirow{2}{*}{$\begin{array}{c}\mathrm{EC}_{\mathrm{e}} \\
\mathrm{dSm}^{-1}\end{array}$} & \multicolumn{4}{|c|}{ Cations (meq/L) } & \multicolumn{4}{|c|}{ Anions (meq/L) } & \multirow{2}{*}{ SAR } & \multirow{2}{*}{ ESP } \\
\hline & & & $\mathrm{Na}^{+}$ & $\mathrm{K}^{+}$ & $\mathrm{Ca}^{2+}$ & SAR & $\mathrm{CO}_{3}{ }^{-2}$ & $\mathrm{HCO}_{3}{ }^{-}$ & $\mathrm{Cl}^{-}$ & $\mathrm{SO}_{4}{ }^{-2}$ & & \\
\hline \multirow{3}{*}{$\begin{array}{c}\mathrm{S}_{1} \\
\text { Hafire }\end{array}$} & $0-30$ & 5.45 & 35.5 & 1.0 & 18.2 & 9.5 & 0.0 & 3.5 & 32.1 & 28.6 & 9.5 & 10.9 \\
\hline & $30-60$ & 5.32 & 33.5 & 1.1 & 17.2 & 9.2 & 0.0 & 3.7 & 31.2 & 26.1 & 9.2 & 10.6 \\
\hline & $60-90$ & 5.81 & 35.1 & 1.1 & 20.2 & 9.9 & 0.0 & 3.4 & 33.5 & 29.4 & 9.0 & 10.2 \\
\hline \multirow{3}{*}{$\begin{array}{c}S_{2} \\
\text { Hafire }\end{array}$} & $0-30$ & 7.77 & 55.5 & 1.6 & 25.2 & 10.5 & 0.0 & 3.5 & 54.5 & 34.8 & 13.1 & 14.5 \\
\hline & $30-60$ & 7.84 & 56.2 & 1.1 & 26.1 & 10.1 & 0.0 & 4.7 & 64.2 & 24.6 & 13.2 & 14.7 \\
\hline & $60-90$ & 8.11 & 58.4 & 1.5 & 27.3 & 9.6 & 0.0 & 4.9 & 53.9 & 38.0 & 13.6 & 15.1 \\
\hline \multicolumn{2}{|c|}{ Irrigation water } & 4.70 & 26.1 & 0.9 & 17.8 & 8.3 & 0.0 & 3.6 & 26.5 & 23.0 & 7.2 & - \\
\hline
\end{tabular}

Electrical conductivity $\left(\mathrm{dS} \mathrm{m}^{-1}\right)$ was measured using a conductivity meter in the water and soil paste extracts. Soluble cations and anions were determined in the soil paste extract following to the method of Page et al. [28]. The particle size distribution of soil, in percent, was measured using the pipette method according to Gee and Bauder [29]. Soil bulk density was determined before the experiment by using the core method according to Klute [30]. The field capacity and permanent wilting 
point were calculated from soil moisture tension curves [31]. The SAR was calculated by the following equation, according to Richards [31]:

$$
\mathrm{SAR}=\mathrm{Na}+\sqrt{ }\left(\mathrm{Ca}^{2+}+\mathrm{Mg}^{2+}\right) / 2
$$

The ESP, following Rashidi and Seilsepour [32], was predicted with the following equation:

$$
\mathrm{ESP}=1.95+1.03 \mathrm{SAR}
$$

The productivity of irrigation water $\left(\mathrm{P}_{\mathrm{IW}}\right)$ was calculated following Ali et al. [33] as follows:

$$
\mathrm{P}_{\mathrm{IW}}=\mathrm{GY} / \mathrm{Wa}
$$

where GY is grain yield $(\mathrm{kg})$ and Wa is water applied $\left(\mathrm{m}^{3}\right)$.

Two experiments were conducted to evaluate the impacts of salinity conditions, planting methods, and gypsum rates on wheat productivity.

In the 1st experiment, gypsum $\left(\mathrm{CaSO}_{4} \cdot 2 \mathrm{H}_{2} \mathrm{O}\right)$ was applied before the tillage of wheat fields in one dose as a soil amendment to decrease the deleterious effects of salinity on wheat productivity. The gypsum required for reducing the initial soil ESP to a 10 in surface layer was calculated according to [34] as follows:

$$
\mathrm{Gr}=\frac{\mathrm{ESP}_{\mathrm{i}}-\mathrm{ESP}_{\mathrm{f}}}{100} * \mathrm{CEC} * 4.1
$$

where $\mathrm{Gr}$ is the gypsum requirement (ton $\mathrm{ha}^{-1}$ ), $\mathrm{ESP}_{\mathrm{i}}$ is the initial soil ESP, $\mathrm{ESP}_{\mathrm{f}}$ is the required soil $\mathrm{ESP}$, and CEC is the cation exchange capacity (meq/100 g).

The wheat cultivar (Gemmeiza 11 variety) was tested in one season with gypsum at four application rates of $0,2.4,7.2$, or $9.6 \mathrm{tha}^{-1}(0 \%, 25 \%, 75 \%$, and $100 \%$ of the gypsum requirement) under two salinity conditions, as follows:

$\mathrm{S}_{1}: 4.7 \mathrm{dS} \mathrm{m}^{-1}$ for irrigation water, $\mathrm{EC}_{\mathrm{w}} ; 5.45 \mathrm{dS} \mathrm{m}^{-1}$ for soil, $\mathrm{EC}_{\mathrm{e}}\left(\right.$ Hafir $\left.^{1}\right)$.

$\mathrm{S}_{2}: 4.7 \mathrm{dS} \mathrm{m}^{-1}$ for irrigation water, $\mathrm{EC}_{\mathrm{w}} ; 7.77 \mathrm{dS} \mathrm{m}^{-1}$ for soil, $\mathrm{EC}_{\mathrm{e}}\left(\mathrm{Hafir}^{2}\right)$.

In the 2nd experiment, the Shandawil wheat variety (Triticum aestivum L.) was grown under farmer conditions in adjacent locations at Al-Dakahlia Gov. with different levels of soil and water salinity in two sites during two successive growing seasons, as follows:

1. Season 2015/2016: Two sites were chosen with different salinity levels for soil $\left(E C_{e}\right)$ and irrigation water $\left(\mathrm{EC}_{\mathrm{w}}\right)$ as follows: $\mathrm{S}_{0}$ : A soil salinity of $2.5 \mathrm{dS} \mathrm{m}^{-1}$ and a water salinity of $0.5 \mathrm{dS} \mathrm{m}^{-1}$ as low salinity level at Talkha. $\mathrm{S}_{1}$ : A soil salinity of $9.0 \mathrm{dS} \mathrm{m}^{-1}$ and a water salinity of $4.0 \mathrm{dS} \mathrm{m}^{-1}$ as moderate salinity at Hafir ${ }^{1}$.

2. Season 2016/2017: Two sites with two salinity levels of water $\left(E C_{w}\right)$ and soil $\left(E C_{e}\right)$ were considered as follows: $\mathrm{S}_{0}$ : A soil salinity of $2.5 \mathrm{dS} \mathrm{m}^{-1}$ and a water salinity of $0.5 \mathrm{dS} \mathrm{m}^{-1}$ as low salinity level at Talkha. $\mathrm{S}_{2}$ : A soil salinity of $12.3 \mathrm{dS} \mathrm{m}^{-1}$ and a water salinity of $7.8 \mathrm{dS} \mathrm{m}^{-1}$ as high salinity at Hafir ${ }^{2}$.

Additionally, three planting methods-traditional flat $\left(\mathrm{T}_{\mathrm{f}}\right)$, raised furrows with a $60 \mathrm{~cm}$ width (F60), and raised beds with a $120 \mathrm{~cm}$ width (F120)—were arranged in both sites in each growing season using randomized complete block with four replicates. The recommended agricultural practices for wheat were done in both growing seasons. The amounts of irrigation water applied to each field were measured with calibrated water pumps. The wheat was irrigated 5 times at a $50 \%$ depletion of the soil-available water, and, at maturity, the plants in each plot were manually harvested.

Statistical analysis: An analysis of variance was done using a randomized complete block design, one-factor model combined with salinity conditions, according to [35]. The means of the studied treatments were compared by the least significant difference (LSD) at the $5 \%$ level [36]. 


\section{Results and Discussion}

The grain yield of wheat was used as a parameter for evaluating productivity under salinity conditions and agricultural practices such as planting methods and the application of gypsum.

\subsection{Effect of Gypsum on Wheat Grain Yield under Salinity Conditions}

The data in Table 5 show significant differences between grain yields with different gypsum rates, especially with higher rates in both salinity conditions. The highest application rate of gypsum $(100 \%$ Gr) achieved the highest grain yield in both salinity conditions ( 8.23 or $6.10 \mathrm{t} \mathrm{ha}^{-1}$ ) with $12.7 \%$ or $24.0 \%$ increases than without gypsum application. The application of gypsum alleviated the adverse effect of salinity stress on wheat with respect to its grain yield. Therefore, the reduction of grain yield due to higher salinity levels was $32.6 \%$ without application of gypsum, but it was decreased by $32.3 \%$ with $25 \%$ Gr, by $29.5 \%$ with $75 \% \mathrm{Gr}$; finally, it was reduced by $25.9 \%$ with the application of $100 \%$ of the gypsum requirement. This may be attributed to gypsum improving the soil's physical properties-i.e., better water infiltration rate, better soil aggregation, and reduced surface crusting - that improve crop rooting and lead to higher yields [22]. This shows the importance of gypsum application to salt-affected soils to overcome salinity stress and to promote flocculation and structure developments in dispersed soils [25], especially when the price of gypsum is relatively low as in Egypt.

Table 5. Grain yield of wheat $\left(\mathrm{t} \mathrm{ha} \mathrm{h}^{-1}\right)$ under different gypsum rates and salinity conditions. Gr: gypsum requirement.

\begin{tabular}{|c|c|c|c|c|c|c|}
\hline \multirow{3}{*}{$\begin{array}{l}\text { Gypsum } \\
\text { Treatment }\end{array}$} & \multicolumn{4}{|c|}{ Salinity Level $^{x}$} & \multirow{3}{*}{ G-Mean } & \multirow{3}{*}{$\mathrm{S}_{1} \stackrel{-\%}{\text { vs. } S_{2}}$} \\
\hline & \multicolumn{2}{|c|}{$S_{1}$ (Hafir $^{1}$ ) } & \multicolumn{2}{|c|}{$S_{2}\left(\right.$ Hafir $\left.^{2}\right)$} & & \\
\hline & $\begin{array}{l}\text { Grain Yield } \\
\text { (ton ha }^{-1} \text { ) }\end{array}$ & $+\%$ & 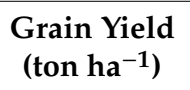 & $+\%$ & & \\
\hline 0.0 & $7.30 \mathrm{~d}$ & 0.0 & $4.92 \mathrm{~h}$ & 0.0 & $6.11 \mathrm{D}$ & 32.6 \\
\hline $25 \% \mathrm{Gr}$ & $7.43 c$ & 1.8 & $5.03 \mathrm{~g}$ & 2.2 & $6.23 \mathrm{C}$ & 32.3 \\
\hline $75 \% \mathrm{Gr}$ & $7.87 \mathrm{~b}$ & 7.8 & $5.55 \mathrm{f}$ & 12.8 & $6.71 \mathrm{~B}$ & 29.5 \\
\hline $100 \% \mathrm{Gr}$ & $8.23 \mathrm{a}$ & 12.7 & $6.10 \mathrm{e}$ & 24.0 & $7.17 \mathrm{~A}$ & 25.9 \\
\hline S-Mean & $7.71 \mathrm{~A}$ & & $5.40 \mathrm{~B}$ & & & 29.9 \\
\hline F-test-S & $* *$ & & $* *$ & & & \\
\hline F-test-G & * & & * & & & \\
\hline F-test-S*G & * & & * & & & \\
\hline
\end{tabular}

\subsection{Effect of Salinity Conditions (ECe and ECw) and Planting Methods}

\subsubsection{Soil Salinity}

The data illustrated in Figure 1 and Appendix A Table A1 show the clear effects of salinity conditions and planting methods on soil salinity in the surface layer after wheat harvesting compared to the initial salinity levels. The data revealed that the soil salinity level was slightly increased with the $\mathrm{T}_{\mathrm{f}}$ method under the moderate salinity level (S1) and the higher salinity level (S2) (3.9\% and 3.5\%, respectively), while with the normal salinity level (S0), it was slightly decreased (2.0\%). On the other hand, planting on a raised furrow (F60) under the S0, S1, and S2 salinity levels increased soil salinity by $2.0 \%, 18.6 \%$, and $21.3 \%$, respectively. In addition, using raised beds (F120) under the S0, S1, and S2 salinity levels caused the highest increases in soil salinity $(4.8 \%, 31.1 \%$, and $31.8 \%$, respectively) over that before planting. Therefore, under $\mathrm{S} 1$ and $\mathrm{S} 2$, the soil salinity values with the $\mathrm{T}_{\mathrm{f}}$ method were lower than that with F60 or F120. This behavior may have been related to the higher amounts of irrigation water applied to the $\mathrm{T}_{\mathrm{f}}$ plots than those applied to both other systems, thus leading to the accumulation of salts with F60 and F120. These results are somewhat in agreement with those obtained by Hassan et al. [15], who found that bed planting reduced water requirements for wheat 
by $25 \%$ relative to the flat planting system. Therefore, in saline-sodic situations, the performance of wheat on beds can be inferior to flat systems, as observed by Hasanuzzaman et al. [20] due to the accumulation of salts.

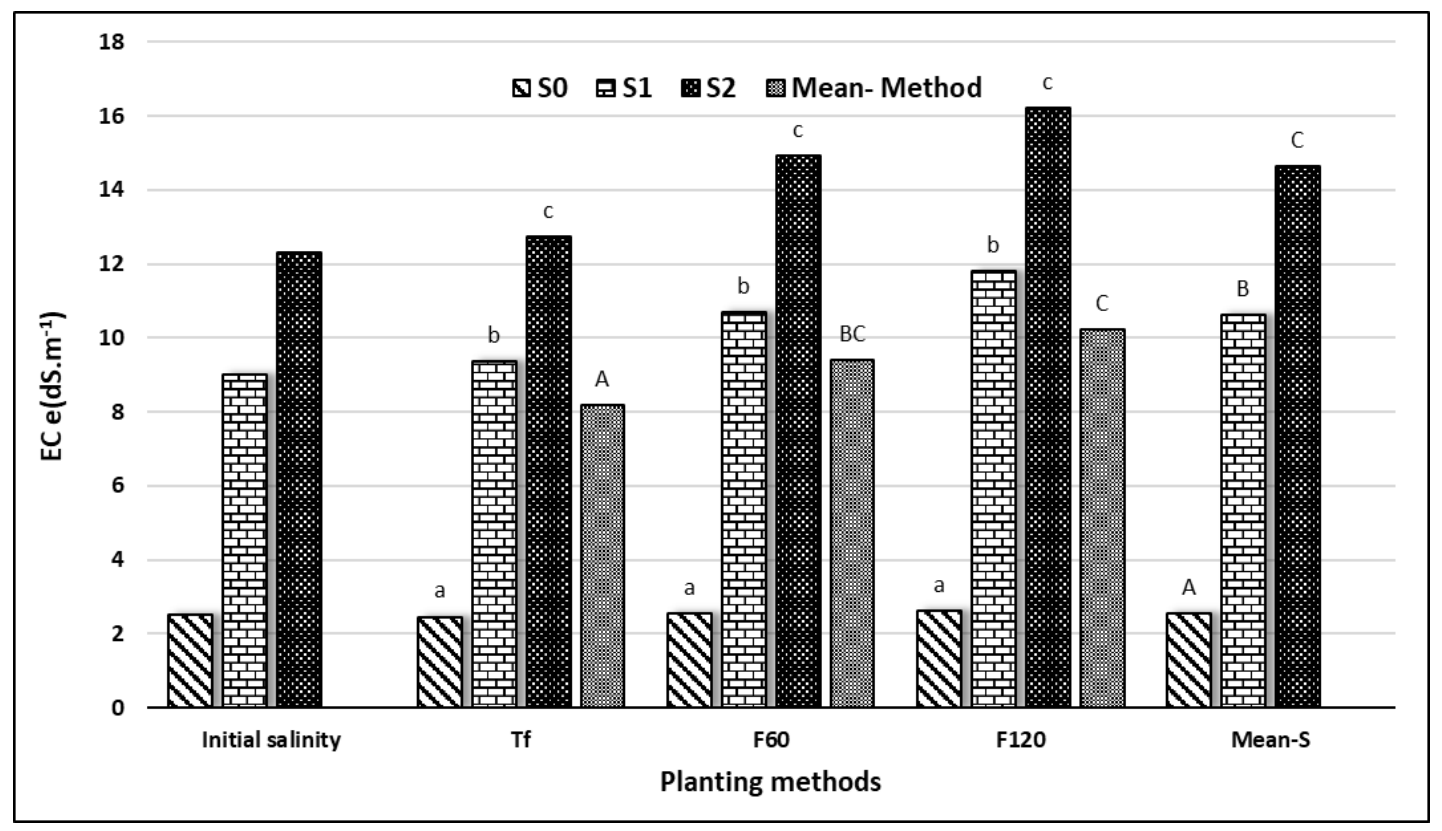

Figure 1. Soil salinity after harvesting under different planting methods and salinity conditions.

\subsubsection{Seasonal Irrigation Water Applied (IWa)}

The total amount of water required and applied (IWa) during the two growing seasons tested in this study were clearly affected by planting methods and salinity conditions, as shown in Table 6 . The mean values of the IWa were slightly increased with increase of salinity levels in both growing seasons. IWa values under S0 and S1 in the 1st season were 5536 and $5707 \mathrm{~m}^{3} \mathrm{ha}^{-1}$, respectively $(+3.1 \%)$, while in the 2nd season, the values with S0 and S2 were 5598 and $5896 \mathrm{~m}^{3} \mathrm{ha}^{-1}$, respectively $(+5.3 \%)$. Additionally, the amount of IWa with S2 in the 2nd season was higher than that with S1 in the 1st season by about $3.3 \%$.

Table 6. Irrigation water applied (IWa $-\mathrm{m}^{3} \mathrm{ha}^{-1}$ ) under different planting methods $(\mathrm{M})$ and salinity conditions (S).

\begin{tabular}{|c|c|c|c|c|c|c|c|c|c|c|}
\hline \multirow{2}{*}{$\begin{array}{l}\text { Planting } \\
\text { Method } \\
\text { (M) }\end{array}$} & \multicolumn{4}{|c|}{ The 1st Season $(2015 / 016)$} & \multicolumn{4}{|c|}{ The 2nd Season $(2016 / 017)$} & \multicolumn{2}{|c|}{$\begin{array}{c}\text { Saving } \% \text { with } \\
\mathrm{F}_{60} \text { and } \mathrm{F} 120 \text { vs. } \mathrm{T}_{\mathrm{f}}\end{array}$} \\
\hline & $\mathrm{S}_{0}$ & $S_{1}$ & Mean-M & $\begin{array}{c}+\% \\
S_{0} \text { vs. } S_{1}\end{array}$ & $\mathrm{~S}_{0}$ & $\mathrm{~S}_{2}$ & Mean-M & $\begin{array}{c}+\% \\
S_{0} \text { vs. } S_{2}\end{array}$ & $\begin{array}{c}\text { 1st } \\
\text { Season }\end{array}$ & $\begin{array}{c}\text { 2nd } \\
\text { Season }\end{array}$ \\
\hline $\mathbf{T}_{\mathbf{f}}$ & 5766 & 6069 & 5918 & 5.3 & 5877 & 6260 & 6068 & 6.5 & 0 & 0 \\
\hline F60 & 5588 & 5730 & 5659 & 2.5 & 5677 & 5930 & 5803 & 4.5 & 4.3 & 4.3 \\
\hline F120 & 5256 & 5318 & 5286 & 1.2 & 5239 & 5497 & 5368 & 4.9 & 10.7 & 11.6 \\
\hline Mean-S & 5536 & 5707 & - & 3.1 & 5598 & 5896 & - & 5.3 & - & - \\
\hline
\end{tabular}

With regard to the effect of planting methods, the data showed that the IWa in the 1st season with $\mathrm{T}_{\mathrm{f}}, \mathrm{F} 60$, and F120 were 5918, 5659, and $5286 \mathrm{~m}^{3} \mathrm{ha}^{-1}$, respectively, and in the 2nd season, they were 6068 , 5803 , and $5368 \mathrm{~m}^{3} \mathrm{ha}^{-1}$, respectively. Meanwhile, using raised furrows in both seasons saved about $4.3 \%$ of water $\left(260 \mathrm{~m}^{3} \mathrm{ha}^{-1}\right)$, while raised beds saved about $11.1 \%$ of irrigation water $\left(675 \mathrm{~m}^{3} \mathrm{ha}^{-1}\right)$, compared to that for traditional flat plots. Therefore, raised beds are always more efficient when water is limited [12], which may be related to the limitations of percolated water due to smaller areas exposed to the irrigation water and the cultivated area being irrigated in a shorter time [19].

On the other hand, the IWa values were clearly affected by the interaction of salinity conditions with planting methods. It could be observed that the highest IWa values (6069 and $6260 \mathrm{~m}^{3} \mathrm{ha}^{-1}$ ) 
were obtained with the $T_{\mathrm{f}}$ method under higher salinity levels in both growing seasons, while the lowest IWa values (5256 and $5239 \mathrm{~m}^{3} \mathrm{ha}^{-1}$ ) were achieved with wheat planted with F120 under S0 in both seasons. Therefore, the effects of higher salinity levels on the IWa under the $\mathrm{T}_{\mathrm{f}}$ method were higher than that with F60 or F120. These results are in harmony with those obtained by Li et al. [16], who identified the usefulness of permanent raised bed technology in terms of higher irrigation water savings with less local machinery and labor costs.

\subsubsection{Grain Yield of Wheat}

The effects of salinity conditions and planting methods on wheat grain yield are shown in Figure 2 and Appendix A Table A2. Regarding the effect of salinity conditions, the data indicated that the grain yields with low salinity levels $\left(\mathrm{S}_{0}\right)$, which represented nearly non-stressed conditions, were significantly higher than those with higher salinity stress in the 1st season $\left(\mathrm{S}_{1}\right)$ or in the 2nd season $\left(\mathrm{S}_{2}\right)$. Regardless of the planting method, the grain yield based on salinity conditions in the 1st season varied from $4.28 \mathrm{tha}^{-1}$ with $\mathrm{S}_{1}$ to $6.01 \mathrm{t} \mathrm{ha}^{-1}$ with $\mathrm{S}_{0}$ with a $27.3 \%$ decrease, while in the 2nd season, it decreased from $7.16 \mathrm{tha}^{-1}$ for $\mathrm{S}_{0}$ to $3.95 \mathrm{tha}^{-1}$ for $\mathrm{S}_{2}$-representing a $44.8 \%$ decrease. Additionally, the grain yield with $S_{1}$ in the 1st season was higher than that with $S_{2}$ in the 2nd season by $9.2 \%$. Therefore, the yields obtained with the salinity conditions can be arranged in the normal descending order: $\mathrm{S}_{0}>$ $S_{1}>S_{2}$. These trends are in harmony with those of Yoshu et al. [36], who reported that decreases in grain yield might be related to the adverse effect of osmotic stress due to drought and salinity.

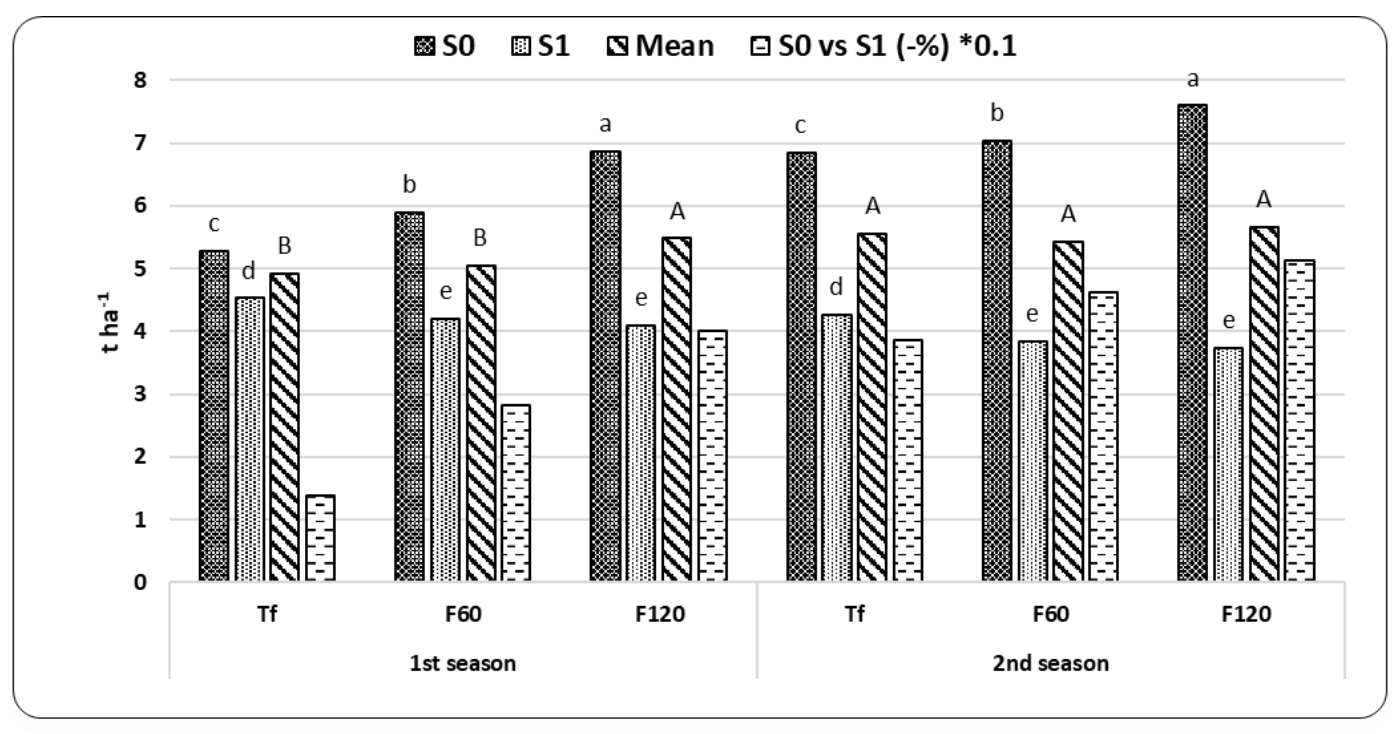

Figure 2. Grain yield (ton ha ${ }^{-1}$ ) under different planting methods (M) and salinity conditions (S).

Concerning the effect of planting methods, the data indicated that the grain yield with planting on $120 \mathrm{~cm}$-raised beds (F120) under the normal salinity condition in both growing seasons (6.89 and $7.60 \mathrm{tha}^{-1}$ ) were superior to the other two planting methods, followed by that with F60 (5.89 and $7.03 \mathrm{t} \mathrm{ha}^{-1}$ ) and the traditional flat method (5.28 and $6.85 \mathrm{t} \mathrm{ha}^{-1}$ ). Thus, the grain yield with different planting methods under normal salinity conditions can be ranked as follows: $\mathrm{F} 120>\mathrm{F} 60>\mathrm{T}_{\mathrm{f}}$. The positive effects of raised beds on wheat yield under normal salinity conditions may be attributed to the better vertical distribution of photo-synthetic active radiation in wheat canopies [16], as well as the fact that the plants in outside rows normally tiller well and appear to spread and cover the gap to the extent that all the light is captured, raised beds reduce anoxia due to the non-flooding of the plant bases [11], weed germination is lower on drier bed surfaces than with the conventional flat layouts [37], and the increase in soil salinity with the raised beds under low salinity stress do not reach injurious levels-although they receive low amounts of irrigation water. These trends were 
confirmed by Zhang et al. [12], who concluded that raised beds had higher wheat yields than those with flat planting.

Contrary trends were observed with higher salinity levels in both growing seasons (S1 and S2). The grain yields under higher salinity conditions with planting methods in both growing seasons showed decreases in the order of $\mathrm{T}_{\mathrm{f}}>\mathrm{F} 60>\mathrm{F} 120$. Therefore, the highest decrease in grain yield was recorded with F120 under S1 in the 1st season (40.0\%) and under S2 in the 2nd season (51.3\%), while the $\mathrm{T}_{\mathrm{f}}$ system recorded the lowest decreases in grain yield under $\mathrm{S} 1$ in the 1 st season (13.8\%) or under $\mathrm{S} 2$ in the 2 nd season (38.6\%). This behavior may be attributed to the fact that the traditional flat plots received higher amounts of irrigation water than both raised furrows or beds, leading to salt accumulation and consequently decreasing the grain yield of wheat grown on raised beds. These results agree with those found by Yadav et al. [19].

The grain yield was affected by the interaction between salinity conditions and planting methods. Thus, the highest grain yield in both seasons (6.86 and $7.60 \mathrm{t} \mathrm{ha}^{-1}$, respectively) was obtained with wheat planted on the F120 system under S0, while the lowest yield was obtained with the same planting method under S1 in the 1st season $\left(4.10 \mathrm{t} \mathrm{ha}^{-1}\right)$ and under S2 in the 2nd season $\left(3.74\right.$ ton ha $\left.{ }^{-1}\right)$. Additionally, it could be observed that decreases in grain yield due to salinity conditions were higher with the furrows or raised beds than with the flat system. These results are in agreement with the observations of [38] and [19], who found that the performance of wheat on beds in saline-sodic situations could be inferior to the conventional flat system.

\subsubsection{Irrigation Water Productivity $\left(\mathrm{P}_{\mathrm{IW}}\right)$}

The concept of irrigation water productivity $\left(\mathrm{P}_{\mathrm{IW}}\right)$ is used either as the yield or net income per unit of water used in evapotranspiration (ET). When water supplies are limited, the yield or the net income from a unit of water should be maximized. The salinity conditions showed significant effects on $\mathrm{P}_{\mathrm{IW}}$ in both growing seasons, as shown in Figure 3 and Appendix A Table A3. The $\mathrm{P}_{\mathrm{IW}}$ values, as $\mathrm{kg}$ grain $\mathrm{m}^{-3}$ water, were decreased in the 1 st season from 1.09 with $\mathrm{S} 0$ to 0.75 with $\mathrm{S} 1$, while in the 2nd season; they decreased from 1.29 with $\mathrm{S} 0$ to 0.66 under $\mathrm{S} 2$. The reasons for the decrease in $\mathrm{P}_{\mathrm{IW}}$ under higher salinity stress were related to the decreases of yield in addition to the increases in applied water.

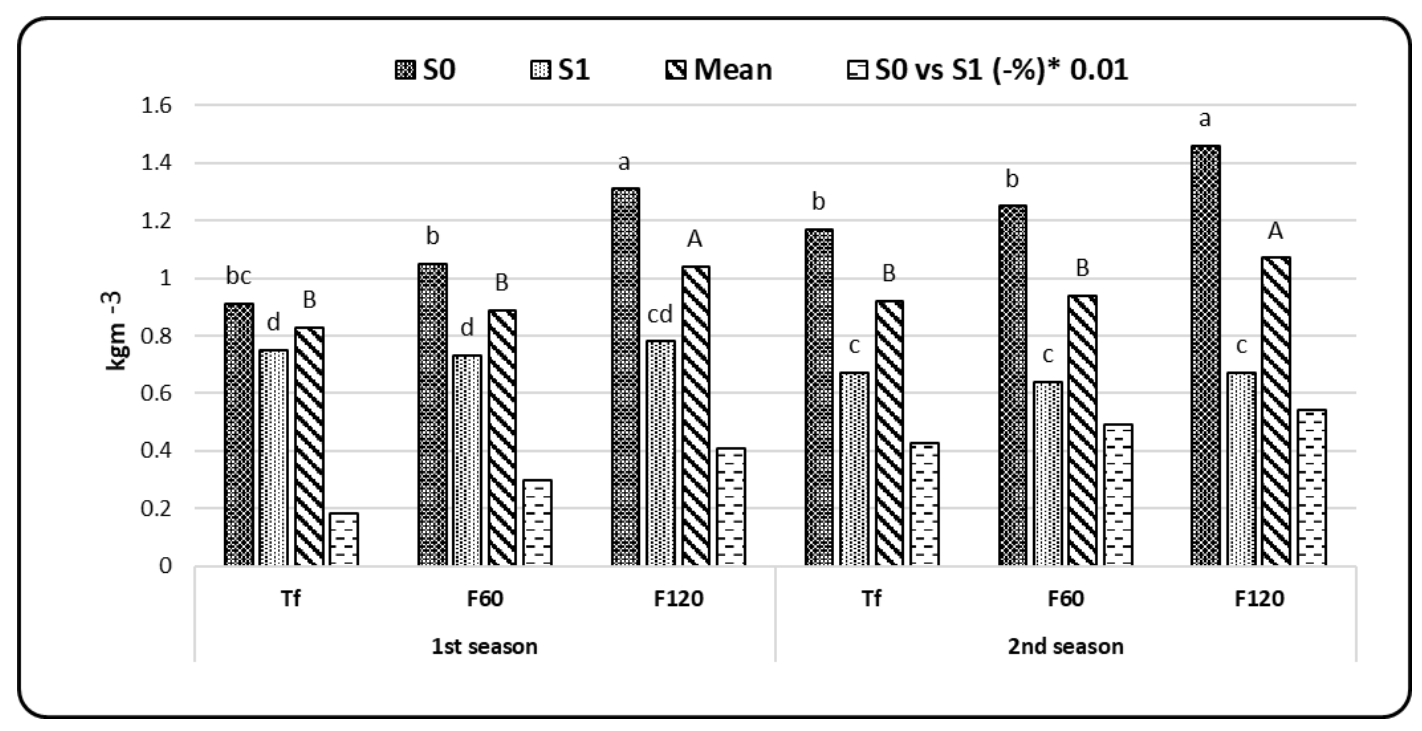

Figure 3. $\mathrm{P}_{\mathrm{IW}}\left(\mathrm{kg} \mathrm{m}^{-3}\right)$ under different planting methods $(\mathrm{M})$ and salinity conditions $(\mathrm{S})$.

Concerning the response of $\mathrm{P}_{\mathrm{IW}}$ to the planting on raised beds, the data showed that $\mathrm{P}_{\mathrm{IW}}$ values increased with F60 and F120 over that with the $\mathrm{T}_{\mathrm{f}}$ method by $7.2 \%$ and $25.3 \%$, respectively, in the 1 st season and by $2.2 \%$ and $16.3 \%$, respectively, in the 2 nd season. The increase of $\mathrm{P}_{\mathrm{IW}}$ with raised beds 
was mainly related to the increase of its yield in addition to the decrease in the irrigation water applied. These results are in agreement with those obtained by Hobbs et al. [10] and Zhang et al. [12].

Due to the contradictory response of $\mathrm{P}_{\mathrm{IW}}$ to salinity stress and planting on raised beds, the highest values were achieved with F120 under S0 in both growing seasons (1.31 and $1.46 \mathrm{~kg} \mathrm{~m}^{-3}$ ), while the lowest values in both seasons $\left(0.73\right.$ and $\left.0.64 \mathrm{~kg} \mathrm{~m}^{-3}\right)$ were recorded with $\mathrm{F} 60$ under higher salinity conditions. This behavior was somewhat similar to that observed by El-Hadidi et al. [39].

Finally, we conclude that the usefulness of raised beds technology should be recommended under normal salinity conditions in terms of higher yields, irrigation water savings, increased water productivity, and, consequently, higher profitability.

\section{Conclusions}

Field experiments were conducted to study the effect of planting methods and gypsum application rates on yield and water productivity of wheat under various salinity levels. It could be concluded that:

a. The application of gypsum alleviated the hazardous impacts of salinity stress on wheat grown in salt-affected soils and/or irrigated by saline irrigation water.

b. Raised bed technology is useful in terms of higher yields, irrigation water savings, and higher water productivity compared with the conventional flat planting method, especially under normal salinity conditions.

c. The decrease in grain yield due to salinity was higher with beds than that with the flat planting method. The $\mathrm{P}_{\text {IW }}$ values decreased under salinity stress due to the decrease of yield and the increase of water applied. The increase of $\mathrm{P}_{\mathrm{IW}}$ with wheat planted on the beds under normal salinity stress was mainly related to the increase of yield and the decrease in the water applied compared to the traditional flat plots, while the opposite trend was observed with higher salinity stresses.

d. Using raised furrows under salinity conditions caused appreciable increases in soil salinity compared to that before planting, while the soil salinity increase with flat plots was lower.

e. Finally, our results suggest that permanent raised beds technology should be used based on higher yields, irrigation water savings, increased water productivity, and higher profitability.

Author Contributions: Writing original draft, H.A.; methodology, H.A. and K.G.; planning and designing the experiment, H.A. and K.G.; editing and reviewing, H.A., K.G. and B.E.; and supervision, B.E. All authors have read and agreed to the published version of the manuscript.

Funding: This research received no external funding.

Acknowledgments: Deep thanks from the authors to Soils, Water, and Environment Research Institute (SWERI), Wheat Research Dept. (Field Crop Research Institute Agricultural Research Centre), Agric. \& Biol. Eng. Dept., (Purdue Univ., USA), and ICARDA Office, Cairo, Egypt for their scientific and technical supports.

Conflicts of Interest: The authors declare no conflict of interest.

\section{Appendix A}

Table A1. Soil salinity after harvesting under different planting methods and salinity conditions.

\begin{tabular}{|c|c|c|c|c|c|c|c|c|}
\hline \multirow{2}{*}{ Planting Method (M) } & \multicolumn{2}{|c|}{$\mathrm{S}_{0}$ (Talkha) } & \multicolumn{2}{|c|}{$S_{1}\left(\right.$ Al-Hafir ${ }^{1}$ ) } & \multicolumn{2}{|c|}{$\mathrm{S}_{2}\left(\mathrm{Al}-\mathrm{Hafir}^{2}\right.$ ) } & \multicolumn{2}{|c|}{ Mean-M } \\
\hline & $\mathrm{dS} \mathrm{m}^{-1}$ & $+-\%$ & $\mathrm{dSm}^{-1}$ & $+\%$ & $\mathrm{dS} \mathrm{m}^{-1}$ & $+\%$ & $\mathrm{~d} S \mathrm{~m}^{-1}$ & $+\%$ \\
\hline Initial soil salinity & 2.50 & 0.0 & 9.00 & 0.0 & 12.30 & 0.0 & 7.93 & 0.0 \\
\hline Traditional flat $\left(\mathrm{T}_{\mathrm{f}}\right)$ & 2.45 & -2.0 & 9.35 & 3.9 & 12.73 & 3.5 & 8.18 & 3.1 \\
\hline Furrow $60 \mathrm{~cm}$ width (T60) & 2.55 & 2.0 & 10.70 & 18.9 & 14.92 & 21.3 & 9.39 & 18.4 \\
\hline Furrow $120 \mathrm{~cm}$ width (F120) & 2.62 & 4.8 & 11.80 & 31.1 & 16.21 & 31.8 & 10.21 & 28.8 \\
\hline Mean-S & 2.54 & 1.6 & 10.62 & 18.0 & 14.62 & 18.9 & 9.26 & 16.8 \\
\hline
\end{tabular}

$\mathrm{S}_{0}: \mathrm{EC}_{\mathrm{w}}$ of $0.5 \mathrm{dSm}^{-1}$ and $\mathrm{EC}_{\mathrm{e}}$ of $2.5 \mathrm{dSm}^{-1}, \mathrm{~S}_{1}: \mathrm{EC}_{\mathrm{w}}$ of $4.0 \mathrm{dSm}^{-1}$ and $\mathrm{EC}_{\mathrm{e}}$ of $9.0 \mathrm{dS} \mathrm{m}^{-1}$ and $\mathrm{S}_{2}: \mathrm{ECW}_{\mathrm{w}} 7.8 \mathrm{dS} \mathrm{m}^{-1}$ and ECe of $12.3 \mathrm{dS} \mathrm{m}^{-1}$. 
Table A2. Grain yield (ton ha ${ }^{-1}$ ) under different planting methods $(\mathrm{M})$ and salinity conditions $\left(\mathrm{S}^{*}\right)$.

\begin{tabular}{|c|c|c|c|c|c|c|c|c|c|}
\hline \multirow{2}{*}{$\begin{array}{l}\text { Planting } \\
\text { Methods ** }\end{array}$} & \multicolumn{4}{|c|}{ The 1st Season $(2015 / 016)$} & \multicolumn{4}{|c|}{ The 2nd Season $(2016 / 017)$} & \multirow{2}{*}{$\begin{array}{c}-\% \\
S_{1} \text { vs. } S_{2}\end{array}$} \\
\hline & $\begin{array}{c}S_{0} \\
\text { Talkha }\end{array}$ & $\begin{array}{c}S_{1} \\
\text { Hafir }{ }^{1}\end{array}$ & Mean-M & $\begin{array}{c}-\% \\
S_{0} \text { vs. } S_{1}\end{array}$ & $\begin{array}{c}\mathrm{S}_{0} \\
\text { Talkha }\end{array}$ & $\begin{array}{c}\mathrm{S}_{2} \\
\text { Hafir }^{2}\end{array}$ & Mean-M & $\begin{array}{c}-\% \\
S_{0} \text { vs. } S_{2}\end{array}$ & \\
\hline$T_{f}$ & $5.28 \mathrm{c}$ & $4.53 \mathrm{~d}$ & $4.92 \mathrm{~B}$ & 13.8 & $6.85 c$ & $4.26 \mathrm{~d}$ & $5.56 \mathrm{~A}$ & 38.6 & 7.3 \\
\hline F60 & $5.89 \mathrm{~b}$ & $4.20 \mathrm{e}$ & $5.05 \mathrm{~B}$ & 28.3 & $7.03 \mathrm{~b}$ & $3.84 \mathrm{e}$ & $5.43 \mathrm{~A}$ & 46.3 & 10.2 \\
\hline F120 & $6.86 \mathrm{a}$ & $4.10 \mathrm{e}$ & $5.48 \mathrm{~A}$ & 40.0 & $7.60 \mathrm{a}$ & $3.74 \mathrm{e}$ & $5.66 \mathrm{~A}$ & 51.3 & 10.4 \\
\hline Mean-S & $6.01 \mathrm{~A}$ & $4.28 \mathrm{~B}$ & - & 27.4 & $7.16 \mathrm{~A}$ & $3.95 \mathrm{~B}$ & - & 45.8 & 9.3 \\
\hline F-test-S & \multicolumn{4}{|c|}{$* *$} & \multicolumn{2}{|c|}{$* *$} & & & \\
\hline$-\mathbf{M}$ & \multicolumn{3}{|c|}{ * } & & \multicolumn{2}{|c|}{ * } & & & \\
\hline$-S^{*} M$ & \multicolumn{2}{|c|}{ * } & & & \multicolumn{2}{|c|}{ * } & & & \\
\hline
\end{tabular}

Table A3. $\mathrm{P}_{\mathrm{IW}}\left(\mathrm{kg} \mathrm{m}^{-3}\right)$ under different planting methods $(\mathrm{M})$ and salinity conditions (S).

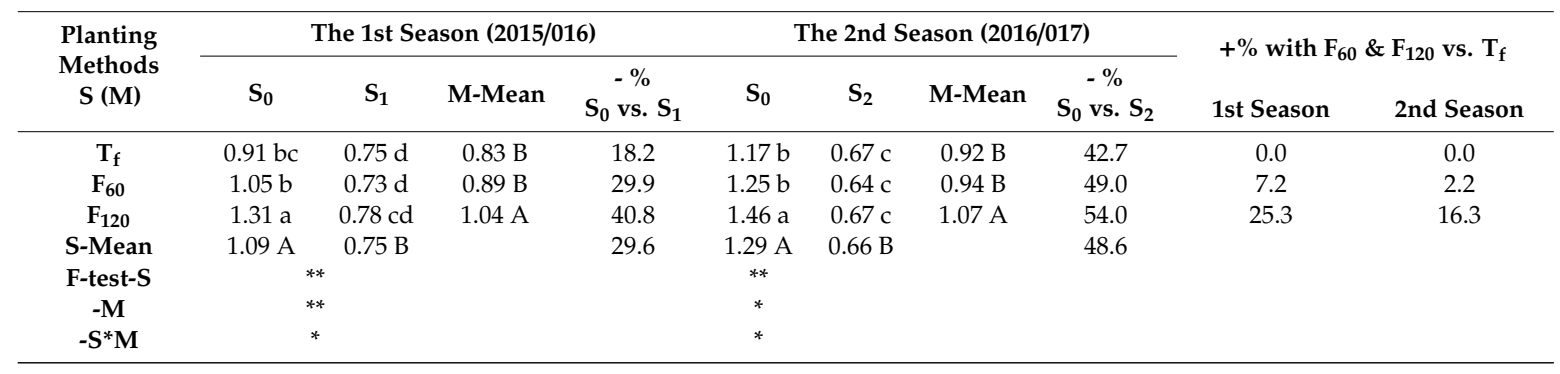

* The same letter means that the values are not significantly different at a $5 \%$ level according to Duncan's test.

\section{References}

1. Nakashima, K.; Takasaki, H.; Mizoi, J.; Shinozaki, K.; Yamaguchi-Shinozaki, K. NAC transcription factors in plant abiotic stress responses. Biochim. Biophys. Acta Gene Regul. Mech. 2012, 1819, 97-103. [CrossRef] [PubMed]

2. Dwivedi, R.S.; Sreenivas, K.; Ramana, K.V. Inventory of salt-affected soils and waterlogged areas: A remote sensing approach. Int. J. Remote Sens. 1999, 20, 1589-1599. [CrossRef]

3. Shalaby, A.; Ali, R.R.; Gad, A. Land Degradation Monitoring in the Nile Delta of Egypt, using Remote Sensing and GIS. Int. J. Basic Appl. Sci. 2012, 1, 283-294.

4. AbdelRahman, M.A.E.; Shalaby, A.; Aboelsoud, M.H.; Moghanm, F.S. GIS spatial model based for determining actual land degradation status in Kafr El-Sheikh Governorate, North Nile Delta. Model. Earth Syst. Environ. 2018, 4, 359-372. [CrossRef]

5. El Baroudy, A.A. Mapping and evaluating land suitability using a GIS-based model. Catena 2016, 140, 96-104. [CrossRef]

6. Amer, M.; Aboelsoud, H.; Omar, E.S. Assessment the Impact of Shallow Groundwater on Soil Salinity and Biomass Yield of Plants Grown in North Nile Delta Using Remote Sensing and GIS Techniques. Egypt. J. Soil Sci. 2018, 58, 57-71. [CrossRef]

7. Jungklang, J.; Saengnil, K.; Uthaibutra, J. Effects of water-deficit stress and paclobutrazol on growth, relative water content, electrolyte leakage, proline content and some antioxidant changes in Curcuma alismatifolia Gagnep. cv. Chiang Mai Pink. Saudi J. Biol. Sci. 2015, 24, 1505-1512. [CrossRef]

8. Bank, W. World Development Report 1992. In Development and the Environment; The World Bank: Washington, DC, USA, 1992; ISBN 0195208765.

9. FAO. World Agriculture: Towards 2015/2030; FAO: Rome, Italy, 2002; Volume 20, ISBN 9251047618.

10. Hobbs, P.R.; Singh, Y.; Giri, G.S.; Lauren, J.G.; Duxbury, J.M. Direct Seeding and Reduced Tillage Options in the Rice-Wheat Systems of the Indo-Gangetic Plains of South Asia; Pandey, S., Mortimer, M., Wade, L., Tuong, T.P., Lopez, K., Hardy, B., Eds.; IRRI: Los Baños, Philiippines, 2002; pp. 201-215.

11. Fischer, R.A.; Sayre, K.; Ortiz Monasterio, I. The effect of raised bed planting on irrigated wheat yield as influenced by variety and row spacing. Aust. Cent. Int. Agric. Res. Proc. 2005, 121, 1-11. 
12. Zhang, J.; Sun, J.; Duan, A.; Wang, J.; Shen, X.; Liu, X. Winter wheat grain yield and grain nitrogen on water use and yield performance of winter wheat in the Huang-Huai-Hai plain of China. Agric. Water Manag. 2007, 92, 41-47. [CrossRef]

13. Freeman, K.W.; Girma, K.; Teal, R.K.; Arnall, D.B.; Klatt, A.; Raun, W.R. Winter wheat grain yield and grain nitrogen as influenced by bed and conventional planting systems. J. Plant Nutr. 2007, 30, 611-622. [CrossRef]

14. Sayre, K.D.; Hobbs, P.R. The raised-bed system of cultivation for irrigated production conditions. Sustain. Agric. Int. Rice-Wheat Syst. 2004, 337-355. [CrossRef]

15. Hassan, I.; Hussain, Z.; Akbar, G. Effect of permanent raised beds on water productivity for irrigated maize-wheat cropping system. Proc. CIAR 2005, 121, 59.

16. Li, Q.; Chen, Y.; Liu, M.; Zhou, X.; Yu, S.; Dong, B. Effects of irrigation and planting patterns on radiation use efficiency and yield of winter wheat in North China. Agric. Water Manag. 2008, 95, 469-476. [CrossRef]

17. Thompson, J.A. Raised beds reduce winter waterlogging. Farmers' Newsletter Large Area 1994, 143, 38.

18. Beecher, H.G.; Thompson, J.A.; Dunn, B.W.; Mathews, S.K. Successful permanent raised beds in the irrigated farming systems of the Murrumbidgee and Murray valleys of New South Wales, Australia. In Evaluation and Performance of Permanent Raised Bed Cropping Systems in Asia, Australia, and Mexico, Proceedings of the ACIA Workshop, Griffith, Australia, 1-3 March 2005; ACIAR: Canberra, Australia, 2005; pp. 129-143.

19. Yadav, A.; Malik, R.K.; Chauhan, B.S.; Kumar, V.; Banga, R.S.; Singh, S.; Yadav, J.S.; Punia, S.S.; Rathee, S.S.; Sayre, K.D. Feasibility of raising wheat on furrow irrigated raised beds in South-Western Haryana. In Proceedings of the International Workshop on, Herbicide Resistance Management and Zero Tillage in Rice-Wheat. Cropping System, Hisar, Indian, 4-6 March 2002; pp. 201-206.

20. Hasanuzzaman, M.; Nahar, K.; Alam, M.M.; Bhowmik, P.C.; Hossain, M.A.; Rahman, M.M.; Prasad, M.N.V.; Ozturk, M.; Fujita, M. Potential use of halophytes to remediate saline soils. Biomed. Res. Int. 2014, 2014, 1-12. [CrossRef] [PubMed]

21. Amer, M. Effect of gypsum, sugar factory lime and molas on some soil proprieties and productivity of sugar beet (Beta vulgaris L.) grown on saline-sodic soils of Nile North Delta. J. Soil Sci. Agric. Eng. 2015, 6, 385-401. [CrossRef]

22. Fisher, M. Amending soils with gypsum. Crops Soils Mag. 2011, 53, 4-9.

23. Shainberg, I.; Alperovitch, N.; Keren, R. Effect of magnesium on the hydraulic conductivity of Na-smectite-sand mixtures. Clays Clay Miner. 1988, 36, 432-438. [CrossRef]

24. Elsaka, M.S.; Aboelsoud, H.M.; Khalifa, T.H. Chitosan and Soluble Calcium Effects on Plant Systems under Salinity Stress. J. Soil Sci. Agric. Eng. 2018, 9, 865-871. [CrossRef]

25. Makoi, J.H.J.R.; Verplancke, H. Effect of gypsum placement on the physical chemical properties of a saline sandy loam soil. Aust. J. Crop Sci. 2010, 4, 556-563.

26. Ghafoor, A.; Gill, M.A.; Hassan, A.; Murtaza, G.; Qadir, A.M. Gypsum: An Economical Amendment for Amelioration of Saline- Sodic Waters and Soils, and for Improving Crop Yields. Int. J. Agric. Biol. 2001, 3, 266-275.

27. Bayoumy, M.A.; Khalifa, T.H.H.; Aboelsoud, H.M. Impact of some Organic and Inorganic Amendments on some Soil Properties and Wheat Production under Saline-Sodic Soil. J. Soil Sci. Agric. Eng. 2019, 10, 307-313. [CrossRef]

28. Page, A.L.; Miller, R.H.; Keeney, D.R. Methods of Soil Analysis. Part 2; Soil Science Society of America: Madison, WI, USA, 1982.

29. Gee, G.W.; Bauder, J.W. Particle-Size Analysis; Wiley Online Library: New York, NY, USA, 1986; Volume 5.

30. Klute, A. Methods of Soil Analysis Part 1; American Society of Agronomy: Madison, WI, USA, 1986.

31. Black, C.A. Methods of Soil Analysis; American Society of Agronomy: Madison, WI, USA, 1965.

32. Rashidi, M.; Seilsepour, M. Modeling of soil exchangeable sodium percentage based on soil sodium adsorption ratio. Int. J. Agric. Biol. 2008, 3, 22-26.

33. Ali, M.H.; Hoque, M.R.; Hassan, A.A.; Khair, A. Effects of deficit irrigation on yield, water productivity, and economic returns of wheat. Agric. Water Manag. 2007, 92, 151-161. [CrossRef]

34. Richards, L.A. Diagnosis and Improvement of Saline and Alkali Soils; LWW. U.S. Department of Agriculture: Washington, DC, USA, 1954; Volume 78, ISBN 0038-075X.

35. Gomez, K.A.; Gomez, A.A. Statistical Procedures for Agricultural Research; John Wiley \& Sons: Hoboken, NJ, USA, 1984. 
36. Yoshiba, Y.; Kiyosue, T.; Nakashima, K.; Yamaguchi-Shinozaki, K.; Shinozaki, K. Regulation of levels of proline as an osmolyte in plants under water stress. Plant Cell Physiol. 1997, 38, 1095-1102. [CrossRef] [PubMed]

37. Ram, H.; Singh, Y.; Timsina, J.; Humphreys, E.; Dhillon, S.S.; Kumar, K.; Kler, D.S. Performance of upland crops on raised beds in northwestern India. J. Chem. Inf. Model. 2005, 12 (Suppl. S1), 1-29.

38. Sharma, P.K.; Bhushan, L.; Ladha, J.; Naresh, R.; Gupta, R.; Balasubramnian, V.; Bouman, B.A.M. Crop-water relations in rice-wheat croppings and water management practices in a marginally sodium medium-textured soil. Water-Wise Rice Prod. 2002, 8, 22-36.

39. El-Hadidi, E.; Ibrahim, M.; Abdel-hafez, S.; Eid, M. Effect of Deficit Irrigation and Raised Bed on Wheat Yield, Water Productivity and Water Saving in North Nile Delta, Egypt. J. Soil Sci. Agric. Eng. 2015, 6, 845-862. [CrossRef]

(C) 2020 by the authors. Licensee MDPI, Basel, Switzerland. This article is an open access article distributed under the terms and conditions of the Creative Commons Attribution (CC BY) license (http://creativecommons.org/licenses/by/4.0/). 